\title{
Promotion of Can Macanan Kaduk Traditional Arts Through Audio Visual Technology
}

\author{
A. Lilik Slamet Raharsono, Christanto Pudji Rahardjo \\ Faculty of Cultural Sciences, University of Jember \\ lilikslamet.sastra@unej.ac.id,hardjokawula@gmail.com
}

\begin{abstract}
Jember Regency is one of the regencies in East Java Province. Here, the growth and development of the culture is extremely rapid and cultural diversity has spread through the southern and northern regions with its respective uniqueness. The southern region is famous for its Javanese culture and the northern region with its Madurese culture. This has led to a combination of the two cultures, resulting in a performing art that is the combination of Javanese and Madurese culture, known as Can Macanan Kaduk. This traditional performing art is an art in Jember that is still maintained by some people. It is needed to support the creativity of this performing art and promote it through audio visual marketing technology, so that it will ultimately become widespread and will be better known by the other people outside of Jember. To realize the program objectives, coaching and mentoring has been carried out, regarding the performing arts management with the artists of Can Macanan Kaduk. We create an audiovisual work for them to help promote Can Macanan Kaduk. The promotion materials are based on audio-visual technology, consisting of documentary film, profile videos and audio-visual advertisement. Through audio-visual promotion and online marketing in websites and offline marketing in DVDs, it is hoped that this traditional performing art, Can Macanan Kaduk, will be widely recognized and gain stronger attention from foreigners, becoming a traditional performing art that characterizes the cultural identity of the Jember Regency.
\end{abstract}

Keywords: Audio Visual Technology, Can Macan Kaduk, Promotion.

\section{INTRODUCTION}

\section{A. Situation Analysis}

Jember is one of the regencies in the East Java Province. Inter-ethnic culture grows here extremely rapidly. The Javanese and Madurese ethnic meetings have produced a new culture, namely Pandhalungan. Pandhalungan covers the regions of Jember, Bondowoso, Situbondo, Lumajang and Probolinggo, as the uniqueness and characteristics influence the Pandhalungan. In the context of culture, the new theme has not received serious attention from cultural observers. In terms of position and area of Pandhalungan, only one area of culture (cultural area) in the eastern part of East Java Province is far from the information center, so that it may be seen as an 'other' or less desirable. ${ }^{l}$ Besides that, the people of Pandalungan are considered to lack cultural attractions, which can be used as Icons as well as other cultural areas in East Java, such as Tengger, Osing, Panaragan, Mataraman, Arek, Madura and Samin. This may be why the area is less attractive to cultural experts. As a consequence of the process of inter-

\footnotetext{
${ }^{1}$ Christanto P Rahardjo, "Pendhalungan: Sebuah 'Periuk Besar' Masyarakat Multikultural" (2017) II:3 Jantra 198.
} 
ethnic communication being interwoven, it has given birth to a new cultural variant with hybrid nuances. ${ }^{2}$ The Pandhalungan community hybridization is a mixture of various languages and multiethnic traditions that shape new cultures. In other words, there is an awareness and personal willingness to participate in other ethnic groups, either because of economic motivation or cultural awareness and that does not mean that they lose the identity of their original ethnic culture. Besides hybridization, which is oriented towards personal involvement, there is also a hybridization that produces new art forms, one of which is Can Macanan Kaduk.

The rapid development of communication and information has caused a decline in people's appreciation, and this is due to the incessant flow of art that is now sweeping across various parts of the country and has narrowed the space for traditional arts. The two contemporary arts that are commonly labeled pop art are more easily appreciated by young people, causing the younger generation to increasingly lack the ability to appreciate traditional arts. The third entry of the new religion considers many local beliefs as primitive, backward, perverted, or forbidden. Thus, the traditional arts that live in the local cultural system cannot be separated from the belief system or custom. Knowledge and years of experience in processing and organizing Can Macanan Kaduk still uses traditional management so that it is unable to compete with today's modern art.

The lack of attention from the local government and the interest of young people towards traditional arts, especially Can Macanan Kaduk, is not only a cause, but also a result. On the basis of these conditions, it is necessary to make efforts and promotions of Can Macanan Kaduk traditional arts through audio visual technology. In an effort to re-promote the arts, it basically concerns two things. First assistance and guidance, as well as the socialization of the performing arts management system, so that they have sufficient understanding of the management of modern art and are able to improve the quality of performances through stage equipment. Second is promoting traditional arts through audio visual technology. Promotional activities have been unattractive or bland, missing a specific target, so that before promoting Can Macanan Kaduk promotion activities, the correct face identity are necessary to be recognized and remembered by the community and the target audience. ${ }^{3}$ In this service activity, the designer is called upon to promote Can Macanan Kaduk traditional arts through audio visual technology that can clarify the positioning of the traditional arts. With a clear promotion through audio visual technology, the traditional art of Can Macanan Kaduk will be re-understood and will gain the attention of the wider community, hopefully becoming one of the traditional arts that is characteristic of the Jember Regency.

Based on the analysis of the situation of the environmental partners, as well as the performance activities by the Bintang Timur arts group, the main problem faced by the Bintang Timur art group concerns the management of the still traditional

\footnotetext{
${ }^{2}$ Mike Featherstone, Scott Lash \& Roland Robertson, Global Modernities (SAGE, 1995), ch Chapter 3: Globalization as Hybridization by Jan Nederveen Pieterse.

${ }^{3}$ Hermawan Kartajaya et al, Positioning Diferensiasi Brand: Memenangkan Persaingan dengan Segitiga (Gramedia Pustaka Utama, 2004).
} 
performances. Partners experiencing difficulties in managing the performing arts, those of whom are still using traditional management, may cause Can Macanan Kaduk art to become increasingly unknown by the community. Additionally, the promotion or marketing of Can Macanan Kaduk traditional art still uses local or printed media, so that the range is limited only around Jember and the surrounding areas, thus the promotion is becoming less and less optimal.

\section{DISCUSSION}

\section{A. Implementation Method}

To solve the problems faced and to achieve the stated objectives, activities are carried out by integrating the elements of good performing arts management knowledge. In addition, knowledge of the method of promotion patterns are performed through offline and online media. The series of activities were carried out as an effort to revive creativity and enthusiasm for the arts and the partners.

\section{B.Activity Description}

The partners are traditional arts actors who have long been involved in the performing arts field, but the lack of knowledge and understanding in carrying out artistic creativity comprehensively, only armed with self-taught experience in the field by stagnating conditions, has resulted in a lack of creativity. In the pattern of marketing traditional art products and based on the analysis of the problems that have been described, the stages of the activities that have been carried out in this program are as follows:

* Socializing of the forms offered

* Training and debriefing of knowledge about performance art management

* Making audio visual works as a marketing tool

* Mentoring the manufacturing process and promotion patterns of traditional art products with the use of offline and online media.

* Evaluating the results of activities

\section{Implementation of Activities}

The promotion of traditional art activities, such as "Can Macanan Kaduk", through audio visual technology is designed to include two activities, namely to conduct mentoring and guidance on performance art management and audio visual works and product marketing, both online and offline. Secondly, it is to produce audio visual works in the form of a company profile. The first activity was designed systematically by providing knowledge, understanding the management of performing arts, as well as the field of making audio visual works, especially the making of company profiles. The output of this activity process is understanding the skills to apply performance art management to the stage, while also having the skills to make rich audio visuals as a marketing tool for traditional art products.

The promotional training activities of Can Macan Kaduk traditional art products is through audio visual technology, which was initiated by the first speaker, Drs. Hary 
Kresno Setiawan, M.M, along with the Can Macanan Kaduk training participants. At the beginning of the briefing, the speaker delivered content related to the importance of performance art management. To improve the quality of Can Macanan Kaduk's performing arts, a reliable production management is needed. Production management is one part of the field of management that has a role in coordinating various activities to achieve goals. To organize this activity, decisions need to be made relating to the efforts in order to achieve the goals, so that the goods and services produced are in accordance with what is planned. Thus, production management involves making decisions related to the production process to achieve the goals of the organization or company. While artistic management is one part of management that has an important role in organizing activities to achieve the beauty of the art that will be performed / held, part of artistic management includes the following: director / drafter, artistic leader, stage manager, stage stylist, light designer, makeup artist and dresser, lighting artist, sound artist, music artist and sounds.

The material presentation, by Drs. Hary Kresno Setiawan, M.M, was followed enthusiastically by the participants. This is evidenced by a number of questions posed by participants regarding the development of performing arts, ranging from traditional music to modern art. Likewise, with the management of performance art from planning to evaluation, by giving this material, it is expected to be applied by the Kaduk Macan can art group so that traditional management can gradually improve. Ultimately, it is hoped to turn into a modern performing arts management, so that the planning, production and evaluation processes can run in accordance with the management of modern art. Traditional cane kaduk traditional arts, over time, will be lonely enthusiasts and fans and this is due to the lack of innovation related to the variety of performances that are still monotonous, as well as the absence of a staging script (resulting in the performances being repeated). This must be addressed critically and immediately by inviting activists to provide training and direction related to the performance process. All activities carried out, both management training and the improvement of the quality of the performance, is solely to increase the quality of the performance of the Kaduk Macan can art, which ultimately can develop rapidly and compete with today's modern art.

The second speaker of the session II activity, Muhammad Zamroni S.Sn., M.Sn. included material about making audio-visual works, namely video profiles and documentary films. In his presentation, the speaker delivered on the types of profiles that can be used to introduce people and products to the public.

The material delivered by Muhammad Zamroni, S.Sn., M.Sn stated that there are principles that must be owned by someone who will create a company profile that attracts the attention of the audience, including the following:

1) Strong message

The main message is what will be conveyed to the community through the company profile and this becomes very important because the community will 
receive and understand the aims and objectives conveyed by the maker of the company profile.

2) Interesting picture

Image or visual becomes very important in making a profile and this is a means of delivering message information accurately through a series of images.

3) Marketing Mix

Product Value or product / service values produced by the company can be reflected by the factors in a particular $7 \mathrm{P}$ marketing mix, namely Product, Price, Promotion, Placement, People, Process, and Physical Evidence. Based on the marketing mix, the company can identify itself with its competitors and then determine which of the seven marketing mix factors is the most effective, ultimately giving the company a competitive advantage over the other brands. After the company successfully identifies its position, then, escalate the position as a selling point in the company profile, especially in terms of product / service.

In essence, the purpose of making a profile, whether it be the profile of individuals, companies and government agencies, it is to introduce someone or a product so that the public can obtain detailed information from the profile submitted. The process of cultivating a profile begins with the selection of objects that will be used as materials to be produced into profiles.

The next material was related to documentary films. Documentary films are films that document the reality of life, and the term documentary is used for all non-fiction films, including films about education, travel and other topics. Based on this definition, initially, all non-fiction films are documentary films. They may record daily activities, such as trains entering the station. Basically, documentary films represent reality. That is, displaying the facts of life once again to the audience. Just like other fiction films, documentary films also get creative treatment so that it is possible to be seen not just as a recording of real events. Viewers often watch documentaries guided by voice overs, interviews with experts, witnesses and opinions of community members. Often times, placement of locations are visible, as well as pieces of direct events and material from the archives found. Variants of documentary films are currently growing, since documentary films were only originally made by people to document an event to serves as a tool to notify the public. Currently documentary films have developed faster, not only as a documentation, but have been used for various purposes, from the television journalistic section, to features, to also being used as an advocacy tool for certain interests.

Activity session III presented the knowledge of making Web Design, delivered by Denny Antyo Hartanto, S.Sn., M.Sn. Web Design is a type of graphic design, aimed at the development and styling of objects in the internet information environment to provide high-end consumer features and aesthetic quality. The definition offered separate web designs, web programming, and emphasized the functional features of a website, as well as web positioning designs as a kind of graphic design. Before 
designing, we should know and understand some of the functions of a website, so that the design is made in accordance with the functions of the website. In general the function of the website is as follows:

a. Communication Function

The website functions as a means for communication in general, as a dynamic web. Because it is made using web programming (server side) it is equipped with facilities that provide communication functions such as web mail, chat and forums.

b. Information function

Emphasizing the quality of content because the purpose of this site is to convey its contents, thus it should contain text, images, graphics and audio visual works. It can also provide information, news, files, company resources and library functions.

c. Entertainment function

As a means of entertainment, the use of animated images and moving elements can improve the quality of the percentage of design, although one should still consider the effect on the download speed. Examples of entertainment functions: online games, online movies and online music.

d. Transaction Function

Web sites can be used as a means for business transactions, including both goods and services. The website can connects certain consumers and community companies through electronic means. Payment can be facilitated through credit cards, transfers or paid directly.

The second activity includes the making of a promotional media process, with all of the modern and sophisticated communication media that is most sought after for those whose purpose is to send information accurately, precisely, easily, efficiently and effectively. Today's development of marketing media has experienced a significant change, seeing as before promotion could only be done through print and electronic media but now the majority of people use the internet technology and audio visual technology. The process of making promotional media in this community service includes:

\section{Web Creation as a Marketing Facility}

Web creation is done to create websites, electronic documents and applications that are on a web server, displaying content and interactive interface features in the form of web pages. This includes text and image (gif, jpeg) elements placed on a page using HTML / XHTML / XML tags. Displaying more complex media (vector graphics, animation, video, sound) requires plug-ins, such as Adobe Flash, QuickTime and Java run-time. Plug-ins are also included in web pages using HTML / XHTML tags. The process of making the web itself had been completed, named canmacanankaduk.com and can be accessed via the internet. The web that has been designed to introduce or promote canoe kaduk art will later be filled with various designs that are being 
prepared, including company profiles, documentaries, audio-visual advertisements and performances of Can Macan Kaduk.

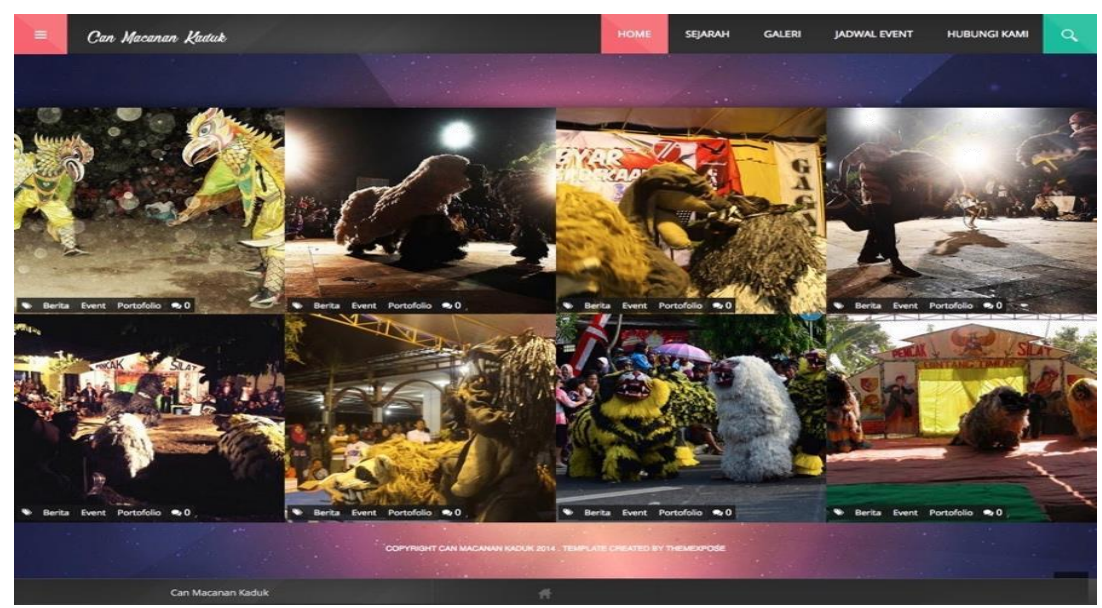

Picture l. The Website of Can Macanan Kaduk

2. Making a Company Profile

The production of audio visual works in the form of a company profile had been carried out in the production process in August 2018. Production activities were carried out for approximately one month. The production of the stirred tiger cans company profile began with various preparations, including formulating ideas or content that would be emphasized for the company profile. After the idea was formulated, the team conducted research with the content that had been formulated. The research that had been carried out included library research, field research by observing the location of shooting and consultations with competent parties, such as Can Macanan Kaduk art leaders, Jember regional art observers and the Jember Regency Tourism Office. The next process of this planning includes setting a time period, choosing the location and crew that will help the production process. In addition, at this stage an estimation of costs is included, namely funding sources and allocation of production costs. The next stage includes completing all permits and correspondence, making arrangements, researching and completing the equipment needed for production. This is done according to the working period. This process begins with preparing all shooting equipment, such as cameras, lights, and other production support equipment.
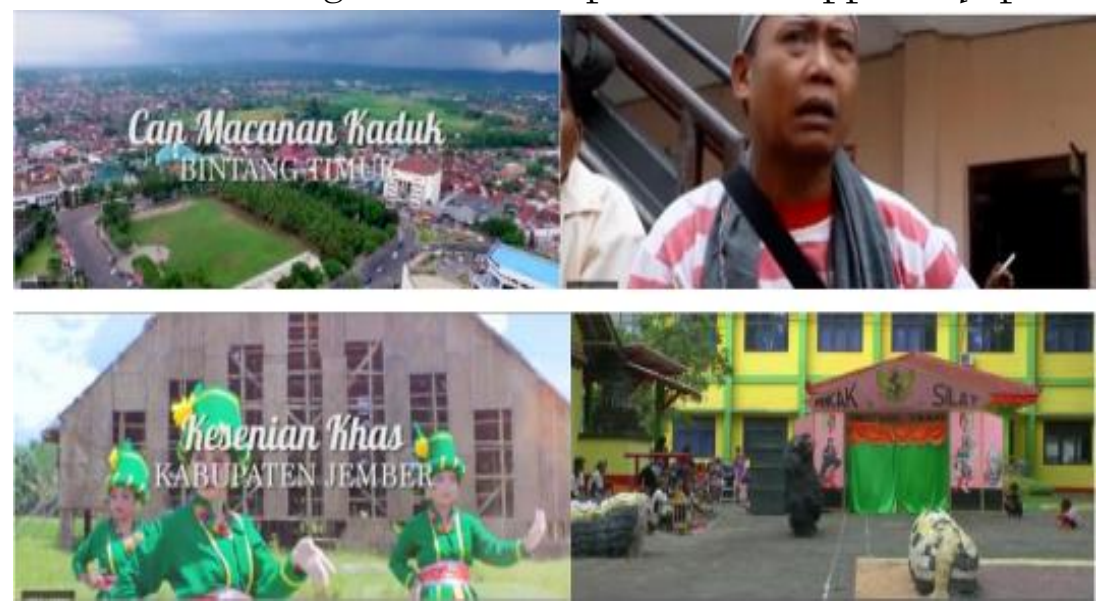

Picture 2. The Company Profile of Can Macanan Kaduk 
The following process after production is post-production. The main activity in the post-production process is editing. After all the image retrieval processes, the results of the production process are entered into the computer for editing. The editing process is the final step for choosing the best image, providing aesthetic touches and visual effects created to add to the appeal of the company profile video that has been designed from the beginning.

\section{Making a Video Show}

Besides making a company profile to introduce the history of the stirred tiger cans, a performance video was made to reintroduce the Kaduk tiger cans from beginning to end of the show. The format of this video is in the form of DVDs that are disseminated to the younger generation in Jember, through schools in Jember Regency.

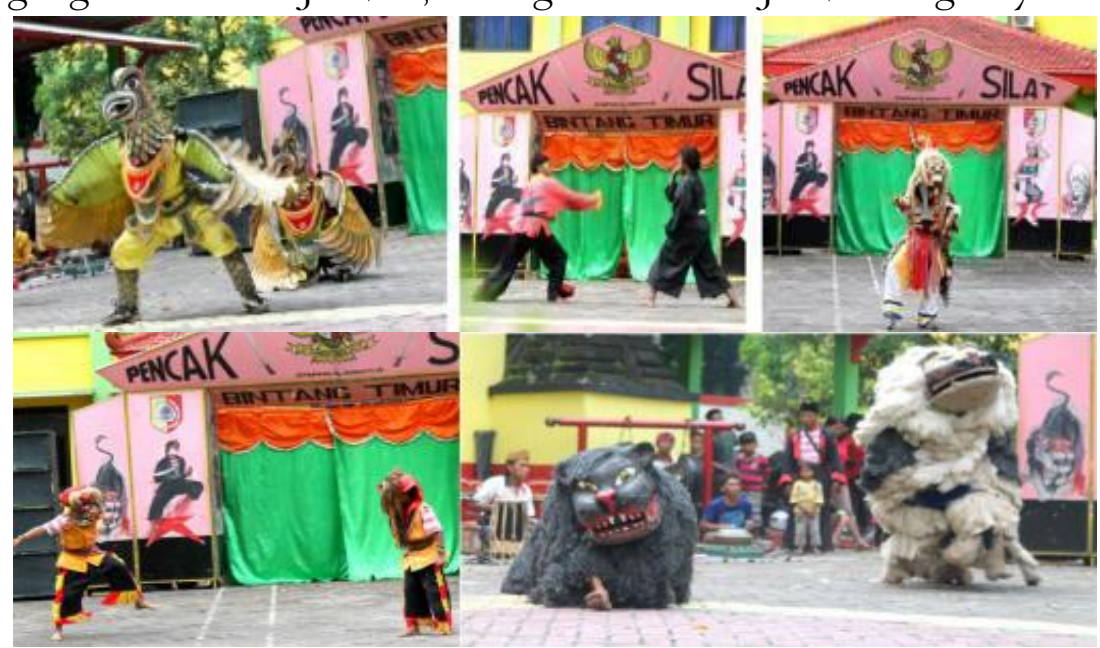

Picture 3. The Performance Video of Can Macanan Kaduk

4. Making Audio Visual Ads

The development of science and technology makes it increasingly easier for us to communicate. Communication is a process that involves the relationship between humans and the surrounding environment. Without communication, the environment would be an irrelevant activity. In other words, humans communicate because they need to establish relationships with the environment. When communicating, humans certainly need communication media. Media communication is all the means used to produce, reproduce, distribute or disseminate and also convey information. ${ }^{4}$ In this case, the communication media is very necessary as a means of marketing / promotion of products / activities.

Making promotional media for audio visual ads requires relatively smaller resources than other audio-visual production, such as television programs or films. But the cultivation process, which consists of the stages of pre-production, production and post-production must still be passed. Among them include exploring the vision and mission of partners, taking stock shoots of products visually and combining them with audio and music narratives to create audio visual advertising products. Then the audio

\footnotetext{
${ }^{4}$ Djito Kasilo, Komunikasi Cinta: Menembus G-Spot Konsumen Indonesia (Kepustakaan Populer Gramedia, 2008).
} 
visual production results will go through the editing and exhibition process and distribution through media, such as television and digital platforms.
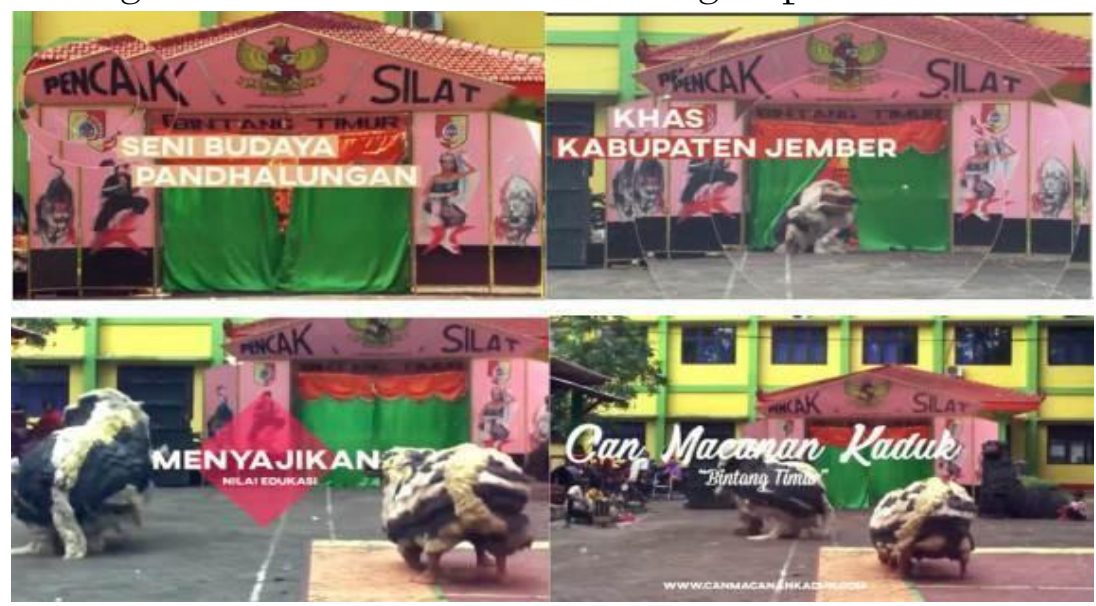

Picture 4. The Audio Visual Ads of Can Macanan Kaduk

5. Improvement of Facilities and Infrastructure Performance

Means and infrastructure are a necessary support for the success of a performance, therefore to make an interesting performance, witnesses need to improve the staging equipment. This includes costumes, musical accompaniment equipment and other supporting equipment, so that the art can compete with the rapidly developing modern world.

Costumes include all of the physical clothing and materials that players wear, along with all their accessories. In the arts, Can Macanan Kaduk has sought costume revamping. Starting from the costume music accompaniment, tiger and other supporters.
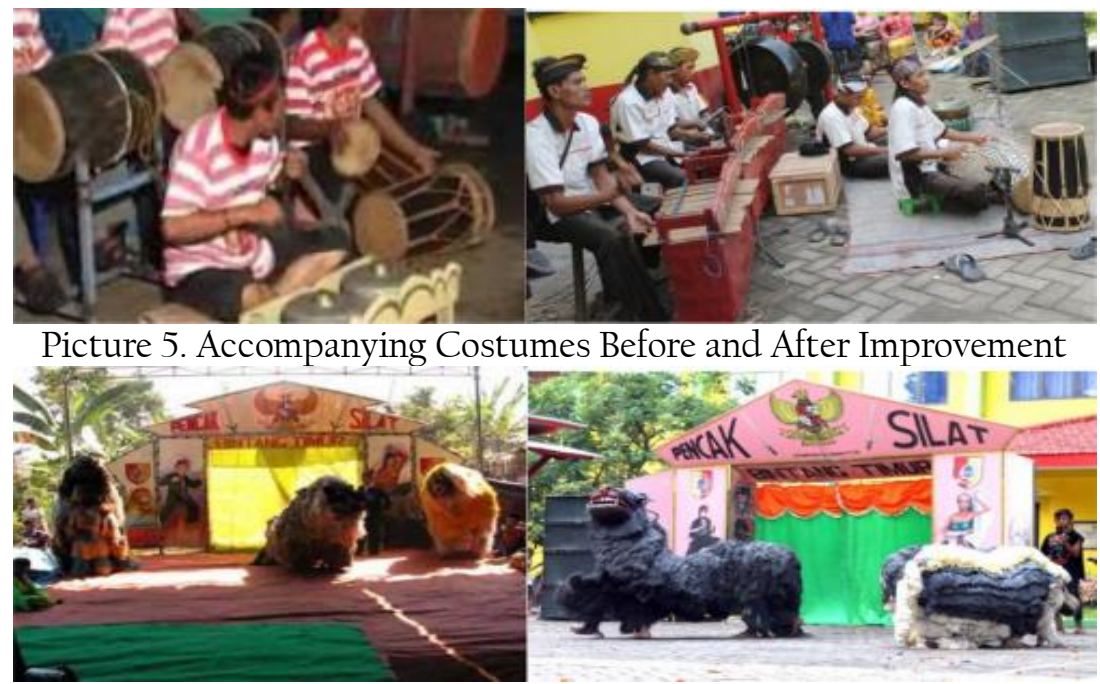

Picture 6. Macanan Costumes Before and After the Settlement

The picture above is one example of the process for revamping the costumes of Can Macanan Kaduk art. Hopefully, with improvements from all fields--management, marketing systems and supporting infrastructure--this art can still exist and survive amid the era of globalization. 


\section{CONCLUSION}

With the provision of this material that can be applied by the Kaduk Macan Can art group, the traditional management can gradually shift to modern performing arts management, so that the planning, production and evaluation processes can run in accordance with the management of modern art. Traditional Cane Kaduk traditional arts, over time, will become lonely enthusiasts due to the lack of innovation related to the variety of performances that are still monotonous and the absence of a staging script, which has resulted in the performances being repeated. This must be addressed critically and immediately by inviting activists, to provide training and direction related to the performance process. All activities carried out by both management training and the improvement of the Kaduk Macan Can art performance quality can ultimately develop rapidly and compete with today's modern art.

The promotion process, with modern and sophisticated communication media, is indeed the most sought after by anyone whose purpose is to send information accurately, precisely, easily, efficiently and effectively. Today, the development of marketing media has experienced a significant development, since previously promotion could only be done through print media. However, the development of internet technology and audio visual technology can be used by the majority of people and institutions to promote various types of products, including traditional Cans of Kaduk tigers. Through company profiles, documentary films, video shows and audio visual advertisements, it is expected to be able to promote and disseminate local wisdom, owned by Kabupaten Jember, so that this art can be recognized by the wider community, both in the countryside and in the big cities. Although it is indeed a difficult mission, with the conditions of the modern era as it is today, yet all efforts need to be sought after so that the artistry of the cane tiger will survive and persist into the future.

\section{BIBLIOGRAPHY}

Christanto P. Raharjo. 2006. Makalah dalam kegiatan jelajah budaya yang diselenggarakan oleh balai kajian Sejarah dan Nilai Tradisional. Yogyakarta.

Fred Wibowo.2007.Dasar-dasar Produksi Program Televisi. Jakarta : PT. Grasindo.

Kasilo, Djito. 2008 Komunikasi Cinta : Menembus G-Spot Konsumen Indonesia. Jakarta : Penerbit Gramedia.

Kertajaya, Hermawan (2004) Positioning, Diferensial, Brand. Jakarta : PT. Gramedia Pustaka Utama.

Kloter, Philip. 2001, Manajemen Pemasaran di Indonesia: Analisis, Perencanaan, Implementasi dan Pengendalian. Jakarta : Salemba Empat. 
Magnadi RH, 2011, Peran Perguruan Tinggi dalam Membangun "City Branding" yang berkelanjutan : Sebuah Upaya untuk Mendorong Pertumbuhan Perekonomian Daerah", Proceeding-Sosial, Ekonomi, dan Humaniora, Vol. 2, No. 1 p. 281-290.

Pieterse, Jan Nederveen, 1995 "Globalization as Hybridization" dalam Mike Featherstone, et.al., (Eds.) Global Modernities , London - Thousand Oaks - New Delhi : SAGE Publications.

\section{OTHER SOURCE}

Interview with Sumarto, Chair of the East Star Campursari Pencak Silat Association Can Macanan Kaduk, July 20, 2018. Jember 